\title{
Luteolytic effects of cloprostenol sodium in lactating dairy cows treated with G6G/Ovsynch
}

\author{
J. P. N. Martins, R. K. Policelli, and J. R. Pursley ${ }^{1}$ \\ Department of Animal Science, Michigan State University, East Lansing 48824
}

\begin{abstract}
The probability of a pregnancy decreases substantially in lactating dairy cows treated with Ovsynch if luteolysis is delayed or incomplete. Two $\mathrm{PGF}_{2 \alpha}$ products are currently approved in the United States for luteolysis in lactating dairy cattle, dinoprost tromethamine and cloprostenol sodium. Cloprostenol has a longer half-life compared with dinoprost, is more resistant to endogenous metabolism, and is maintained in circulation longer. We hypothesized that cloprostenol could reduce the time to complete luteolysis compared with dinoprost because of differences in half-life. Lactating dairy cows received the same presynchronization strategy (G6G; $25 \mathrm{mg}$ of $\mathrm{PGF}_{2 \alpha}-2 \mathrm{~d}-100 \mu \mathrm{g}$ of $\mathrm{GnRH}-6$ $\mathrm{d}-100 \mu \mathrm{g}$ of $\mathrm{GnRH}-7 \mathrm{~d}$ - final $\mathrm{PGF}_{2 \alpha}$ treatment). At the time of the final $\mathrm{PGF}_{2 \alpha}$, cows $(\mathrm{n}=35)$ were randomly assigned to receive either $500 \mu \mathrm{g}$ of cloprostenol or $25 \mathrm{mg}$ of dinoprost. Blood samples were collected daily before and serially after $\mathrm{PGF}_{2 \alpha}$ treatment to analyze circulating concentrations of progesterone $\left(\mathrm{P}_{4}\right)$ and estradiol $\left(\mathrm{E}_{2}\right)$. Ultrasound examinations of ovaries were performed to measure sizes of follicles and corpora lutea (CL) and determine time of ovulation. Considering only cows with complete luteolysis, mean circulating $\mathrm{P}_{4}$ was lower for cows given cloprostenol than for those given dinoprost between 0 and $12 \mathrm{~h}$ postinjection, but not at 24,36 , or $48 \mathrm{~h}$. A rapid decrease in $\mathrm{P}_{4}$ was observed $1 \mathrm{~h}$ after $\mathrm{PGF}_{2 \alpha}(6.54 \pm 0.27$ to $3.77 \pm 0.22 \mathrm{ng} /$ $\mathrm{mL})$ followed by a complete rebound $1 \mathrm{~h}$ later $(3.77 \pm$ 0.22 to $5.07 \pm 0.31 \mathrm{ng} / \mathrm{mL}$ ) followed by a steady decline in both treatment groups. Serum concentrations of $\mathrm{E}_{2}$ were greater at $48 \mathrm{~h}$ posttreatment in cloprostenoltreated cows $(2.74 \pm 0.15 \mathrm{pg} / \mathrm{mL})$ than in dinoprosttreated cows $(2.37 \pm 0.19 \mathrm{pg} / \mathrm{mL})$. Cows that did not have complete luteolysis did not ovulate $(0 / 7)$ during the 6 -d period following treatment. Time to complete luteolysis and ovulation was $29.1 \pm 1.1$ versus $29.4 \pm$ 1.7 and 101 versus $103 \mathrm{~h}$ posttreatment in cloprostenol compared with dinoprost. A negative relationship was
\end{abstract}

Received July 26, 2010.

Accepted February 7, 2011

${ }^{1}$ Corresponding author: pursleyr@msu.edu observed between $\mathrm{P}_{4}$ at $12 \mathrm{~h}$ posttreatment and concentrations of $\mathrm{E}_{2} 48 \mathrm{~h}$ posttreatment $\left(\mathrm{b}=-0.6905 ; \mathrm{R}^{2}=\right.$ 0.23). In summary, cows treated with cloprostenol had lower concentrations of $\mathrm{P}_{4}$ for the first $12 \mathrm{~h}$ following treatment and subsequently greater concentrations of $\mathrm{E}_{2}$ compared with dinoprost, although no differences were observed in these $2 \mathrm{PGF}_{2 \alpha}$ analogs for time to complete luteolysis or time to ovulation.

Key words: cloprostenol sodium, dinoprost tromethamine, luteolysis, Ovsynch

\section{INTRODUCTION}

Pharmacological control of luteolysis is a key component of Ovsynch programs in lactating dairy cows $\left(\mathrm{GnRH}-7 \mathrm{~d}-\mathrm{PGF}_{2 \alpha}-2 \mathrm{~d}-\mathrm{GnRH}-16 \mathrm{~h}-\mathrm{AI}\right.$; Pursley et al., 1995, 1997a,b). Two types of $\mathrm{PGF}_{2 \alpha}$ products are commercially available in the United States, dinoprost tromethamine, a tromethamine salt of the natural $\mathrm{PGF}_{2 \alpha}$, and cloprostenol sodium, a synthetic analog. Cloprostenol has a benzyl chlorine ring that makes this molecule more resistant to endogenous metabolism compared with dinoprost. Therefore, cloprostenol has approximately a 23 -fold longer biological half-life compared with dinoprost (McCracken et al., 1999; approximately 3 h vs. 8 min).

Several studies (Pursley et al., 1997b; Moreira et al., 2000; Souza et al., 2007) using Ovsynch indicated that incomplete or delayed luteolysis following the final $\mathrm{PGF}_{2 \alpha}$ is a problem. At the time of $\mathrm{PGF}_{2 \alpha}$ of Ovsynch more than 1 corpus luteum (CL) could be present depending on the stage of the estrous cycle at which Ovsynch is initiated. For example, if Ovsynch is initiated following deviation of the dominant follicle from subordinates during the first follicular wave, the dominant follicle will likely ovulate to the GnRH-induced LH surge and a new CL and follicular wave may develop. Thus, at time of $\mathrm{PGF}_{2 \alpha} 7 \mathrm{~d}$ later, at least a 7 -d and an older CL will be present in the ovaries.

Ovsynch induces ovulation with a final GnRH-induced LH surge $48 \mathrm{~h}$ after PGF $_{2 \alpha}$ (Pursley et al., 1995) to allow for timed-artificial insemination $16 \mathrm{~h}$ after final GnRH. Serum concentrations of progesterone $\left(\mathbf{P}_{4}\right)$ following $\mathrm{PGF}_{2 \alpha}$ must decline to $<0.5 \mathrm{ng} / \mathrm{mL}$ by $2 \mathrm{~d}$ after 
injection or the probability of pregnancy is diminished (Souza et al., 2007; Brusveen et al., 2009). Subnormal concentrations of $\mathrm{P}_{4}$ at the time of AI may reduce uterine contractility given that $\mathrm{P}_{4}$ decreases the number of oxytocin, angiotensin II, and estrogen receptors in the uterus and antagonizes estrogen induction of estrogen receptors in the uterus, especially in the myometrium (Graham and Clarke, 1997). Delayed regression (prolonged $\mathrm{P}_{4}$ clearance) or incomplete regression may have a negative indirect effect on estradiol-17 $\beta\left(\mathbf{E}_{\mathbf{2}}\right)$ production (Bridges and Fortune, 2003).

The objective was to determine differences in dynamics of luteolysis between dinoprost tromethamine and cloprostenol sodium at the $\mathrm{PGF}_{2 \alpha}$ injection of the Ovsynch protocol without the final administration of GnRH. We hypothesized that circulating concentrations of $\mathrm{P}_{4}$ would be lower following cloprostenol sodium compared with dinoprost tromethamine utilized at the $\mathrm{PGF}_{2 \alpha}$ of Ovsynch and in turn enhance subsequent concentrations of $\mathrm{E}_{2}$ compared with dinoprost tromethamine.

\section{MATERIALS AND METHODS}

\section{Management of Cows}

This trial was conducted between May and October 2007 at the Michigan State University Dairy Teaching and Research facility (East Lansing). Four groups of lactating Holstein dairy cows between 45 and 85 DIM with milk production (mean \pm SEM) during the week of treatment of $45.6 \pm 0.32 \mathrm{~kg} / \mathrm{d}$ were used. Cows were housed in a tie-stall barn with free access to water and fed twice daily with a TMR consisting primarily of corn and alfalfa silages and ground corn balanced to NRC (2001) recommendations. Cows were milked twice daily. The Institutional Animal Care and Use Committee at Michigan State University approved all animal-related procedures.

\section{Calculation of Sample Size and Definition of Complete Luteolysis}

Number of cows needed per treatment was calculated utilizing G*Power 3.0 (Faul et al., 2007). The "MANOVA Test for Repeated Measures Between Factors" power analysis indicated that 26 subjects were needed to detect a $0.5 \mathrm{ng} / \mathrm{mL}$ difference in $\mathrm{P}_{4}$ concentrations between 2 treatments with $\alpha=0.05$ and $\beta=0.8$. To determine the effect of treatment on $\mathrm{P}_{4}$ and $\mathrm{E}_{2}$ following treatment, only cows that had complete luteolysis (defined by cows with serum $\mathrm{P}_{4}$ concentrations $<0.5$ $\mathrm{ng} / \mathrm{mL} 56 \mathrm{~h}$ following treatment) and had continued decrease of serum $\mathrm{P}_{4}$ concentrations for the next $3 \mathrm{~d}$ were used. Effect of treatment on a percentage of cows with complete luteolysis was analyzed in a larger group of cows in a subsequent trial reported in the companion paper (Martins et al., 2011). Approximately 15\% of cows were expected to have incomplete luteolysis; therefore, "n" was increased to account for this difference.

\section{Treatment and Data Collection}

Fifty-four cows received pre-Ovsynch treatments, which consisted of an injection of $500 \mu \mathrm{g}$ of cloprostenol (P1; Estrumate, Schering-Plough Animal Health, Union, NJ), followed in $2 \mathrm{~d}$ with $100 \mu \mathrm{g}$ of GnRH (G1; Ovacyst, IVX Animal Health Inc., St. Joseph, MO); 6 d later, the first GnRH of Ovsynch was initiated (100 $\mu \mathrm{g}$ of GnRH, G2; Figure 1). Only cows that had basal concentrations of $\mathrm{P}_{4}$ after $\mathrm{P} 1$ and ovulation characterized by the disappearance of a dominant follicle and subsequent formation of a new CL by $48 \mathrm{~h}$ after G1 and G2 were included in the experiment. Cows ( $\mathrm{n}=$ 35 ) that met these criteria were blocked by parity and randomly assigned within block to treatments of either $500 \mu \mathrm{g}$ of cloprostenol (Estrumate; $\mathrm{n}=17$ ) or $25 \mathrm{mg}$ of dinoprost (Lutalyse, Pfizer Animal Health, Kalamazoo, MI; $\mathrm{n}=18$ ) $7 \mathrm{~d}$ after G2. Retrospectively, cows with decreasing $\mathrm{P}_{4}$ before treatment were excluded from analyses. Although Ovsynch normally includes $\mathrm{GnRH}$ approximately $2 \mathrm{~d}$ following $\mathrm{PGF}_{2 \alpha}$, the experiment did not include this final GnRH to assess the effect of treatment on follicular growth and peak concentrations of $\mathrm{E}_{2}$. Thus, cows were allowed to manifest estrus and ovulation via endogenous mechanisms. All injections were administered i.m. with either an 18-gauge (injections of $\mathrm{PGF}_{2 \alpha}$ ) or a 20-gauge (injections of $\mathrm{GnRH}$ ) 3.8$\mathrm{cm}$ needle in the semimembranosus or semitendinosus muscles.

Blood samples were collected daily from P1 until treatment by coccygeal venipuncture before ultrasound examinations and before any injection of either $\mathrm{GnRH}$ or $\mathrm{PGF}_{2 \alpha}$. An indwelling catheter was placed in the jugular vein 2 or $3 \mathrm{~d}$ before treatment $(0 \mathrm{~h})$ to collect blood samples at frequent intervals. Blood samples were collected from jugular catheters from treatment $(0 \mathrm{~h})$ to ovulation or $144 \mathrm{~h}$ after treatment if cows did not ovulate. Blood collections were made every $60 \mathrm{~min}$ for the first $12 \mathrm{~h}$ after treatment, every $2 \mathrm{~h}$ between 12 and $24 \mathrm{~h}$, every $4 \mathrm{~h}$ between $24 \mathrm{~h}$ and $72 \mathrm{~h}$, and every $6 \mathrm{~h}$ between $72 \mathrm{~h}$ and ovulation or $144 \mathrm{~h}$. Blood samples were collected using Vacutainer tubes without anticoagulant (BD Vacutainer, Preanalytical Solutions, Franklin Lakes, NJ) and refrigerated for 6 to $12 \mathrm{~h}$. Se- 


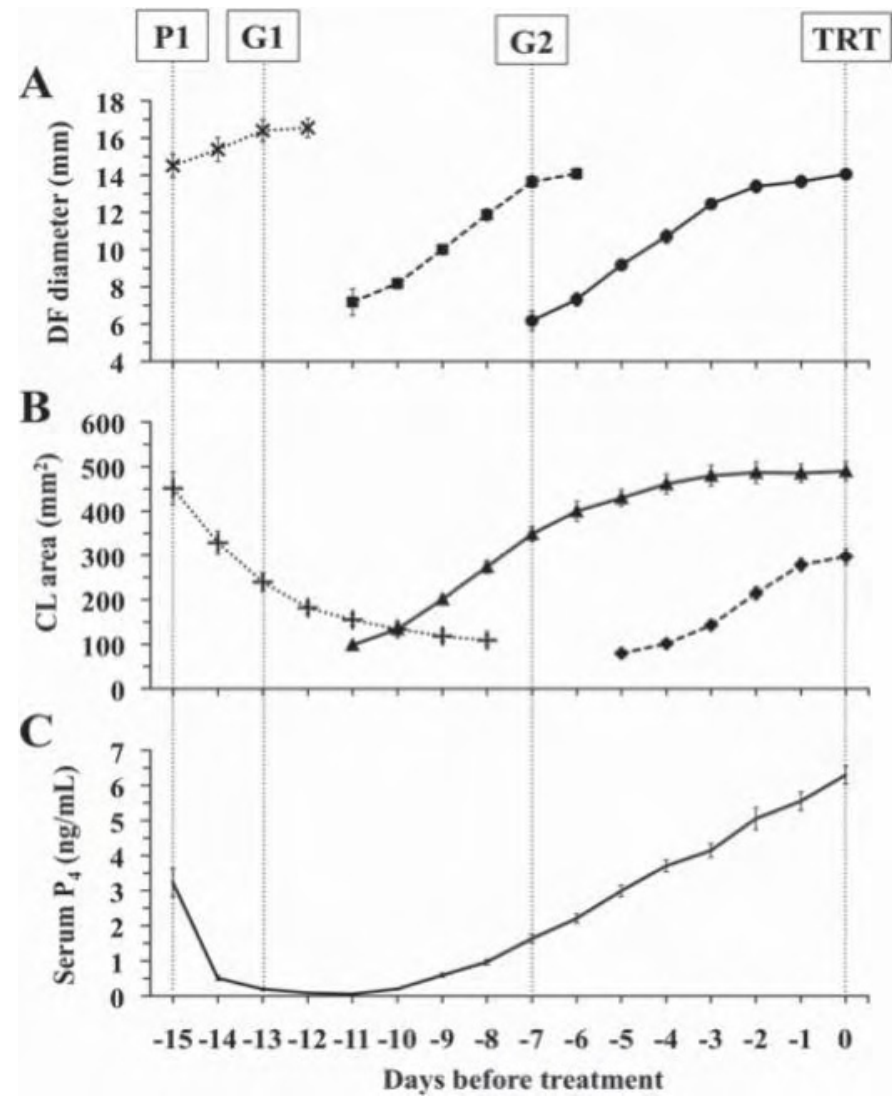

Figure 1. Description of follicle and corpora lutea (CL) development and progesterone $\left(\mathrm{P}_{4}\right)$ concentrations before treatment in lactating dairy cows. (A) Mean diameter $( \pm$ SEM) of dominant follicles $(\mathrm{DF} ; \mathrm{mm})$ in cows $(\mathrm{n}=29)$ at first $\mathrm{PGF}_{2 \alpha}(\mathrm{P} 1 ; \cdots \times \cdots)$ and in cows that ovulated following the first $(\mathrm{G} 1 ; \cdots \times \cdots)$ and second $(\mathrm{G} 2 ;-------)$ injections of $\mathrm{GnRH}$, and the final preovulatory follicle that spontaneously ovulated within $144 \mathrm{~h}$ following treatment (TRT; - - ). (B) Corpora lutea area $\left(\mathrm{mm}^{2}\right)$ in cows $(\mathrm{n}=26)$ with a single functional $\mathrm{CL}$ at first $\mathrm{PGF}_{2 \alpha}(\mathrm{P} 1 ; \cdots+\cdots)$ and with single ovulations $(\mathrm{n}=29)$ to the first (G1; - - -) and second (G2; --- --) injections of GnRH. (C) Serum concentrations of $\mathrm{P}_{4}(\mathrm{ng} / \mathrm{mL})$ are described in relation to each pretreatment injection of $\mathrm{PGF}_{2 \alpha}(\mathrm{P} 1)$ and $\mathrm{GnRH}$ (G1 and G2). Timing of pretreatment injections of $\mathrm{PGF}_{2 \alpha}$ and $\mathrm{GnRH}$ is designated with vertical dotted lines. Cows $(n=6)$ with multiple ovulations following G1 or G2 were not included although growth and development of follicles and CL from these cows had similar patterns to those of cows with single ovulations.

rum was separated by centrifugation at $2,000 \times g$ for $20 \mathrm{~min}$ at $4^{\circ} \mathrm{C}$ and stored at $-20^{\circ} \mathrm{C}$ for later hormonal analyses.

Transrectal ultrasound examinations were conducted daily from P1 until treatment, every $12 \mathrm{~h}$ for $3 \mathrm{~d}$, and then every $6 \mathrm{~h}$ until detection of ovulation or $144 \mathrm{~h}$ posttreatment using a real-time, B-mode, Aloka SSD$500 \mathrm{~V}$ ultrasound machine with a $7.5-\mathrm{MHz}$ linear array probe (Aloka Co. Ltd., Wallingford, CT). Height and width of the largest size of CL and the antrum of each follicle $>4 \mathrm{~mm}$ in diameter were measured with built-in calipers. Follicular and luteal measurements were re- corded in an ovarian map for each cow with date and time of examinations. Mean follicular diameter (D) was calculated by the average of height $(\mathrm{H})$ and width $(\mathrm{W})$ of each follicle ( $\mathrm{D}=\mathrm{H}+\mathrm{W} / 2)$. If a fluid-filled central cavity was detected within the CL, a cross-section area of the cavity was determined in the same way as a cross-section area of the total CL. Total luteal area of each CL was calculated subtracting the cavity area from the total CL area. The following equation was used to calculate CL and cavity area: $0.5 \mathrm{H} \times 0.5 \mathrm{~W} \times$ $\pi$ (Kastelic et al., 1990). Cows at time of treatment (0 h) had a minimum of 2 and maximum of 4 CL.

\section{Hormonal Assays}

Concentrations of $\mathrm{P}_{4}$ were quantified in serum via RIA (Coat-A-Count Progesterone, Siemens Diagnostics, Los Angeles, CA). Inter- and intraassay CV were 9.2 and $5.5 \%$, respectively, for high $\mathrm{P}_{4}$ quality controls, and 9.6 and $6.6 \%$, respectively, for low $\mathrm{P}_{4}$ quality controls. Sensitivity of the assay was $0.02 \mathrm{ng} / \mathrm{mL}$. Estradiol concentrations were quantified in a subset group of serum samples, including samples 0 (time of treatment), 24, and $48 \mathrm{~h}$, and every $12 \mathrm{~h}$ between $48 \mathrm{~h}$ and ovulation or until $144 \mathrm{~h}$ in cows that did not ovulate. Serum samples $(500 \mu \mathrm{L})$ were ether extracted in duplicate and then measured using a modified version of a commercially available RIA MAIA kit (Polymedco Inc., Cortland Manor, NY; Prendiville et al., 1995). Inter- and intraassay CV were 8.9 and $13.5 \%$, respectively. Sensitivity of the assay was $0.5 \mathrm{pg} / \mathrm{mL}$.

\section{Statistical Analyses}

Data were tested for normality of residuals with the Shapiro-Wilk test or Studentized residual plots for each variable. Variables that did not fulfill assumptions for normality were transformed by natural $\log$ and reanalyzed. For clarity, actual means of the data are presented. Discrete variables were analyzed by least-squares ANOVA, using the GLM procedure of SPSS (version 16.0, SPSS Inc., Chicago, IL). Repeatedmeasures variables such as mean concentrations of $\mathrm{P}_{4}$ and $\mathrm{E}_{2}$ over time were analyzed using the MIXED procedure with the REPEATED statement with cows nested in treatment specified in the SUBJECT option of SAS (version 9.2, SAS Inst. Inc., Cary, NC). For the MIXED procedure, fit statistic parameters for unstructured, compound symmetry, first-order autoregressive, heterogeneous compound symmetry, and heterogeneous first-order autoregressive covariance structures were tested. The covariance structure with the lowest values for the Bayesian information criterion was used for the analyses. Only cows that had complete luteolysis and 
ovulation by $144 \mathrm{~h}$ after treatment were analyzed for repeated measures. Serum $\mathrm{P}_{4}$ concentrations over time were analyzed in the following periods: $-24 \mathrm{~h}$ from treatment to $12 \mathrm{~h}$ after treatment, 12 to $24 \mathrm{~h}, 24$ to 48 $\mathrm{h}$, and 48 to $90 \mathrm{~h}$ after treatment. Parity, treatment, time, and their interactions were included in the original model. Interactions that were $P>0.2$ were removed from the model. Only time, treatment, parity, treatment by time, and parity by time remained in the final model for effect of treatment on serum $\mathrm{P}_{4}$ concentrations. Serum concentrations of $\mathrm{E}_{2}$ were analyzed from 0 to $96 \mathrm{~h}$ after treatment. In addition, parity, treatment, time, and their interactions were included in the original model. Only treatment, time, and their interactions remained in the final model for serum $\mathrm{E}_{2}$ analyses. Parity, treatment by parity, parity by time, and group by parity by time interactions were not significant $(P>$ 0.20 ) and were removed from the final model. A onetailed test was utilized for treatment effects because our hypothesis was that $\mathrm{P}_{4}$ would be less and $\mathrm{E}_{2}$ would be greater following treatment with cloprostenol.

Effects of ovulatory follicle diameter at time of G1 and $\mathrm{G} 2$ on $\mathrm{P}_{4}$ and CL area at time of treatment were tested using regression analyses with the REG procedure of SAS. Effect of serum $\mathrm{P}_{4}$ concentrations at $12 \mathrm{~h}$ after treatment on serum $\mathrm{E}_{2}$ concentrations at 24 and $48 \mathrm{~h}$ after treatment were analyzed by the REG procedure of SAS. Effect of time from complete luteolysis to ovulation was analyzed by the REG procedure of SAS.

\section{RESULTS}

\section{Pretreatment Validation}

Figure 1 describes dominant follicle and CL growth before treatment. All cows $(\mathrm{n}=35)$ had luteolysis following P1 and ovulation and a new follicular wave following G1 and G2. Thus, all cows had at least $1 \mathrm{~d}-13$ and $1 \mathrm{~d}-7 \mathrm{CL}$ and a preovulatory follicle $7 \mathrm{~d}$ from induction (G2) of emergence at time of treatment. Three cows had $2 \mathrm{~d}-13$ and $1 \mathrm{~d}-7 \mathrm{CL}$, one cow had $1 \mathrm{~d}-13$ and 2 d- 7 CL, and 2 cows had 2 d- 13 and 2 d- 7 CL (4 cows were in the cloprostenol sodium group and 2 cows were in the dinoprost tromethamine group). The diameter of preovulatory follicles at time of treatment for cows with single ovulations $(\mathrm{n}=26)$ did not differ $(P=0.12)$ between treatments or parities $(P=0.15)$ and averaged $13.3 \pm 0.3 \mathrm{~mm}$. Luteal areas of d-13 CL and d-7 CL were not different $(P=0.6$ and $P=0.6)$ between treatments, with areas of $446.3 \pm 17.8 \mathrm{~mm}^{2}$ and 273.2 $\pm 17.1 \mathrm{~mm}^{2}$, respectively. Serum $\mathrm{P}_{4}$ concentrations $24 \mathrm{~h}$ before $(5.4 \pm 0.2$ and $5.6 \pm 0.3 \mathrm{ng} / \mathrm{mL}$ for cloprostenol sodium and dinoprost tromethamine; $P=0.6)$ and at time of treatment $(6.0 \pm 0.3$ and $6.3 \pm 0.4 \mathrm{ng} / \mathrm{mL}$ for cloprostenol sodium vs. dinoprost tromethamine; $P=$ $0.5)$ were not different between treatments. Serum $\mathrm{P}_{4}$ concentrations for treatments combined were $6.1 \pm 0.2$ $\mathrm{ng} / \mathrm{mL}$ at time of treatment (Figure 1), ranging from 3.6 to $9.0 \mathrm{ng} / \mathrm{mL}$ in individual cows.

Follicle size at time of G1 and G2 had a direct effect on size and function of the resulting CL (Figure 2). In follicles that ovulated in response to G1 and G2, the sizes of follicles at time of each injection of $\mathrm{GnRH}$ were related to luteal area (G1, $P=0.01 ; \mathrm{G} 2, P=0.04)$ and $\mathrm{P}_{4}$ concentrations $(\mathrm{G} 1, P<0.001 ; \mathrm{G} 2, P<0.001)$ at time of treatment.
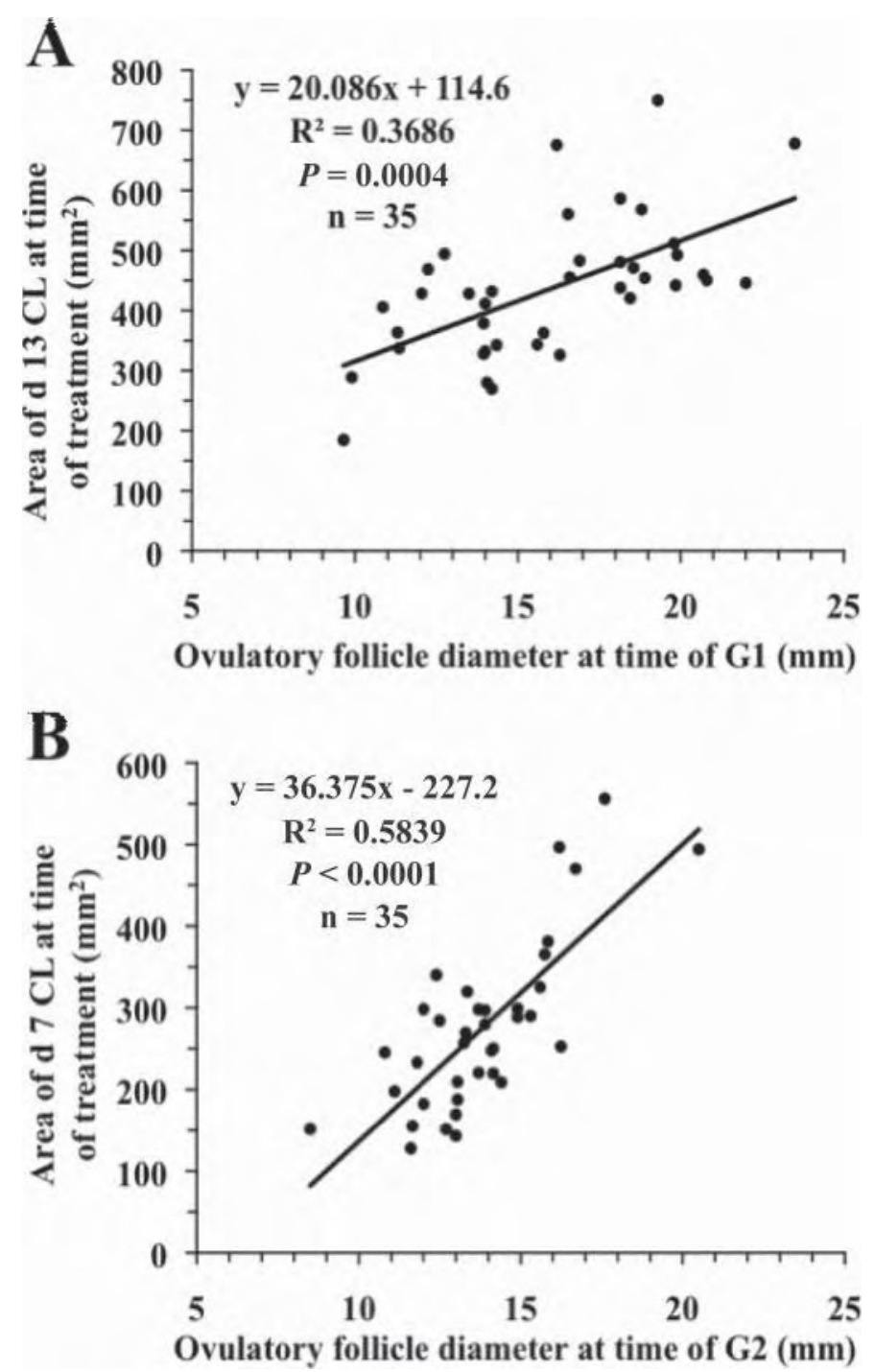

Figure 2. Regression analyses of the relationship between ovulatory follicle diameter $(\mathrm{mm})$ at time of the first $(\mathrm{G} 1 ; \mathrm{A})$ and second (G2; B) injections of $\mathrm{GnRH}$ and area of corpora lutea (CL; $\mathrm{mm}^{2}$ ) that developed following ovulation of these ovulatory follicles measured at time of treatment with $\mathrm{PGF}_{2 \alpha}(\mathrm{n}=35)$ in lactating dairy cows. 


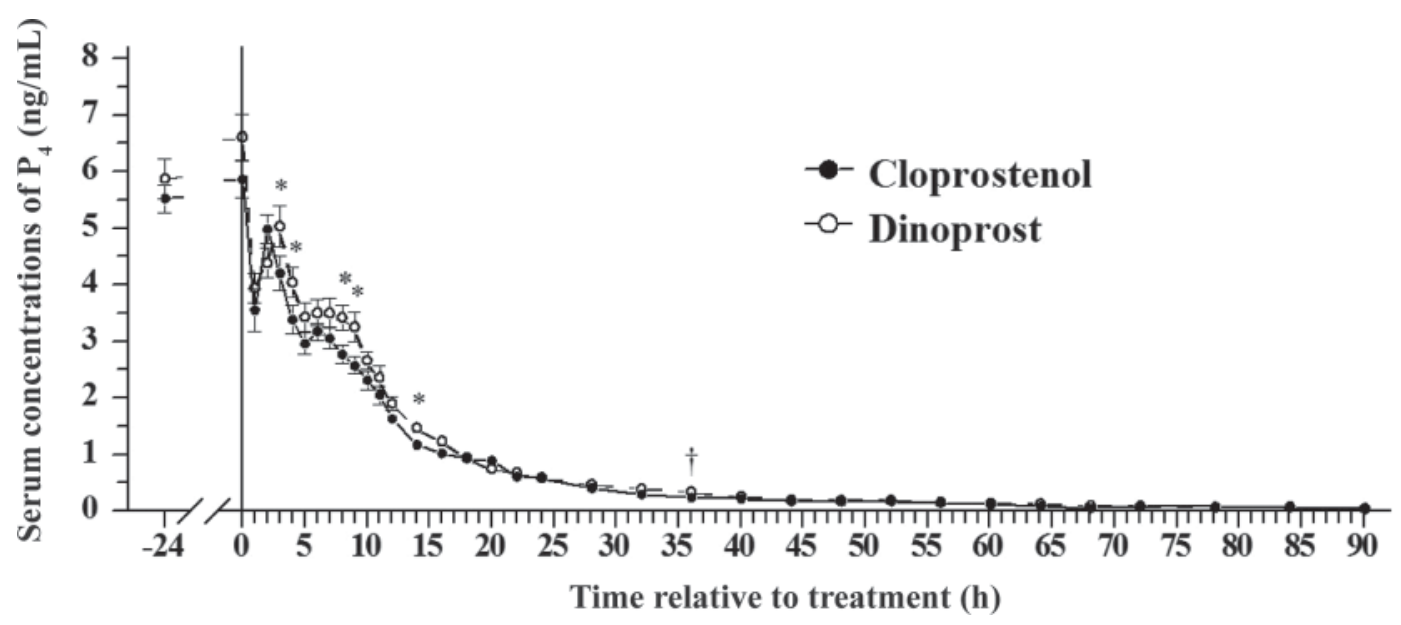

Figure 3. Mean $\left( \pm\right.$ SEM) serum progesterone $\left(\mathrm{P}_{4}\right)$ concentrations $(\mathrm{ng} / \mathrm{mL})$ from $1 \mathrm{~d}$ before to $90 \mathrm{~h}$ following treatment with cloprostenol sodium compared with dinoprost tromethamine in lactating dairy cows with at least one d-7 corpus luteum (CL) and one d-13 CL that had complete luteolysis by $56 \mathrm{~h}$ after $\mathrm{PGF}_{2 \alpha}$ and ovulated by $144 \mathrm{~h}$ after treatment $(27 / 35)$. Concentrations of $\mathrm{P}_{4}$ during this first 12 -h period were different between treatments $(P=0.025)$ but not different from 12 to $24(P=0.46), 24$ to $48(P=0.16)$, or 48 to $90 \mathrm{~h}(P=0.12)$ after treatment. $\dagger P<0.10$ and ${ }^{*} P<0.05$.

Milk production from $3 \mathrm{~d}$ before to $3 \mathrm{~d}$ after treatments was not different $(P=0.3)$ between treatments $(44.0 \pm 2.9$ and $47.2 \pm 2.5 \mathrm{~kg} / \mathrm{d}$ for cloprostenol sodium and dinoprost tromethamine, respectively). Milk production was different $(P<0.0001)$ among first $(\mathrm{n}=12$; $35.4 \pm 1.5 \mathrm{~kg} / \mathrm{d})$, second $(\mathrm{n}=16 ; 47.0 \pm 2.0 \mathrm{~kg} / \mathrm{d})$ and $\geq$ third parities $(\mathrm{n}=7 ; 60.0 \pm 2.5 \mathrm{~kg} / \mathrm{d})$. Parity had no effect $(P=0.9)$ on treatment outcomes.

\section{Effect of Treatment on Dynamics of Luteolysis and Ovulation}

An effect of $\mathrm{PGF}_{2 \alpha}$ type on serum concentrations of $\mathrm{P}_{4}$ was observed for the first $12 \mathrm{~h}$ following treatment $(P=0.025$; Figure 3$)$. Cows treated with cloprostenol sodium had a more rapid decrease in $\mathrm{P}_{4}$ during this period compared with dinoprost tromethamine. Specifically, cows treated with cloprostenol sodium had lower serum $\mathrm{P}_{4}$ concentrations $3(P=0.021), 4(P=0.025), 8$ $(P=0.015)$, and $9 \mathrm{~h}(P=0.008)$ after treatment. Mean serum $\mathrm{P}_{4}$ concentrations were not different between types of $\mathrm{PGF}_{2 \alpha}$ from 12 to $24 \mathrm{~h}(P=0.46$; Figure 3$)$. Cows treated with cloprostenol sodium had lower $(P=$ 0.02 ) serum $\mathrm{P}_{4}$ concentrations at $14 \mathrm{~h}$ after treatment compared with cows treated with dinoprost tromethamine. Treatment effects were not apparent $(P=0.16)$ 24 to $48 \mathrm{~h}$ posttreatment, and no effect of treatment $(P$ $=0.12$ ) was observed from 48 to $90 \mathrm{~h}$ posttreatment.

Mean time between treatment and complete luteolysis ranged from 18 to $40 \mathrm{~h}$ and was not different $(P=$ $0.8)$ between cloprostenol sodium $(29.1 \pm 1.1 \mathrm{~h})$ and dinoprost tromethamine groups $(29.4 \pm 1.7 \mathrm{~h})$. Mean interval from treatment to ovulation ranged from 87 to $123 \mathrm{~h}$ and was not different $(P=0.56)$ between clo- prostenol sodium $(101 \pm 2 \mathrm{~h})$ and dinoprost tromethamine $(103 \pm 2 \mathrm{~h})$ treatments. Interval from complete luteolysis to ovulation ranged from 55 to $93 \mathrm{~h}$, with a mean interval of $72.5 \pm 8.3 \mathrm{~h}$. Parity did affect $(P$ $=0.04)$ time to regression. Second-parity cows had a shorter time to complete luteolysis compared with firstparity cows ( 26.5 vs. $32.0 \mathrm{~h} ; P=0.02)$, with a tendency observed for the comparison with $\geq$ third-parity cows ( 26.5 vs. $31.6 \mathrm{~h} ; P=0.07)$. The size of the preovulatory follicles at the final measurement before ovulation for cows with single ovulations was not different $(P=0.39)$ for cloprostenol sodium $(18.0 \pm 0.5 \mathrm{~mm})$ and dinoprost tromethamine $(18.6 \pm 0.4 \mathrm{~mm})$.

Seven cows did not have complete luteolysis. Two of the 7 cows that did not have complete luteolysis had delayed luteolysis at 90 and $114 \mathrm{~h}$ from treatment and ovulated 156 and $180 \mathrm{~h}$ after treatment, respectively, with intervals of $66 \mathrm{~h}$ between complete luteolysis and ovulation. Five of the 7 cows that did not have complete luteolysis had a decrease in serum $\mathrm{P}_{4}$ concentrations to $<1 \mathrm{ng} / \mathrm{mL} 36 \mathrm{~h}$ posttreatment. Four of these cows subsequently had an increase in serum $\mathrm{P}_{4}$ concentrations to $>1 \mathrm{ng} / \mathrm{mL}$ from 36 to $84 \mathrm{~h}$ after treatment, and 1 of these cows maintained subluteal concentrations (between 0.5 and $1 \mathrm{ng} / \mathrm{mL}$ ) until $144 \mathrm{~h}$ posttreatment. Examples of cows that did not have complete luteolysis by $56 \mathrm{~h}$ posttreatment are in Figure 4 .

\section{Effect of Treatment on Subsequent Concentrations of $E_{2}$}

Mean serum $\mathrm{E}_{2}$ concentrations were greater $(P=$ 0.02 ) at $48 \mathrm{~h}$ after treatment for cloprostenol sodium compared with dinoprost tromethamine (Figure 5). 

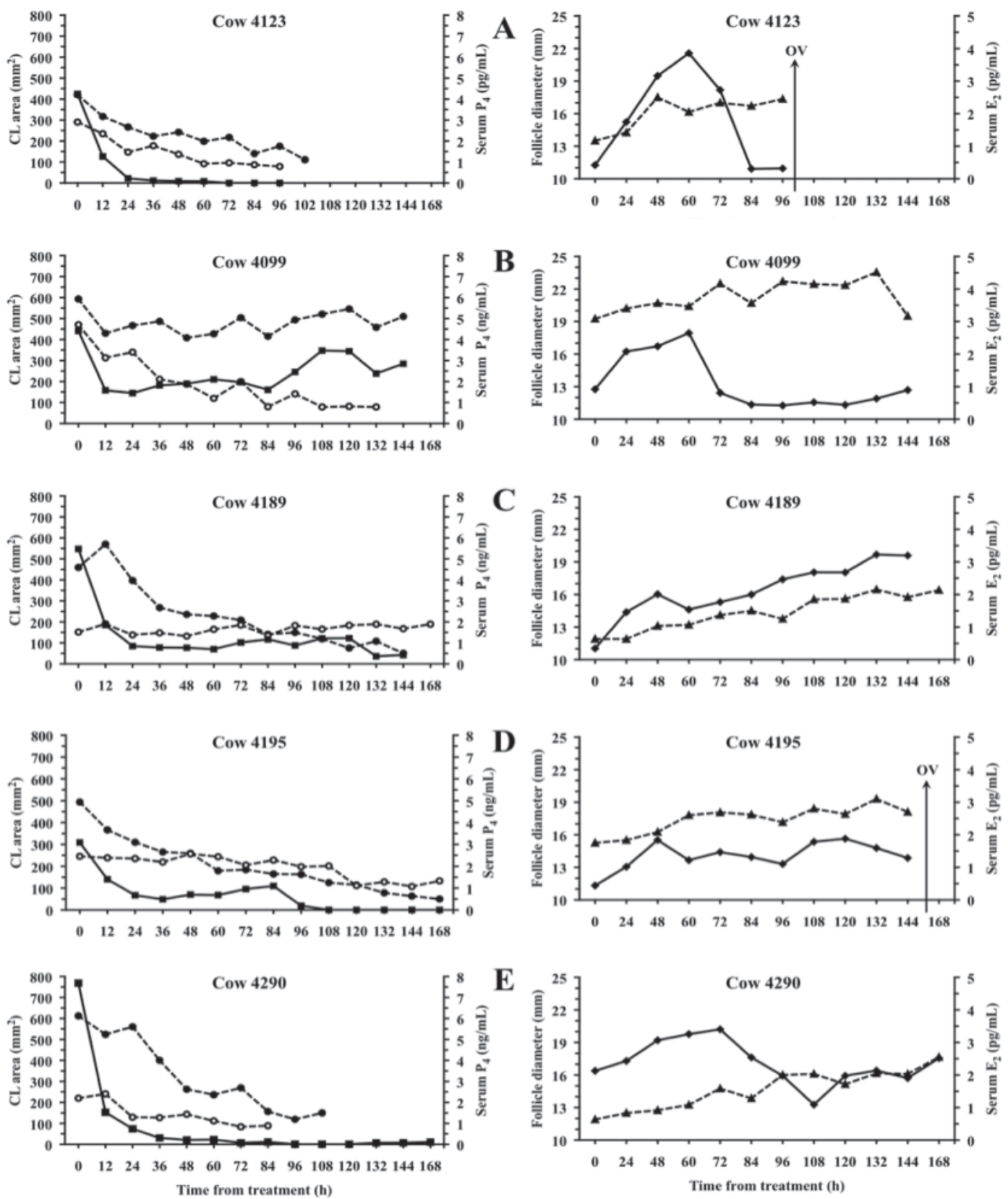

Figure 4. Individual profiles of lactating dairy cows that typified various outcomes following treatment with cloprostenol sodium compared with dinoprost tromethamine in lactating dairy cows. Graphs on left show corpora lutea (CL) areas (mm²) of d 13 (---@---) and d 7 CL (---O---), and serum concentrations of $\mathrm{P}_{4}(-\mathbf{-}-)$ after treatment. Graphs on right show dominant follicle diameter (--- $\mathbf{\Delta - - - )}$ and serum concentrations of estradiol $\left(\mathrm{E}_{2} ;---\right)$ ) after treatment. Panel A (cow \# 4123) describes a cow that had complete luteolysis by $56 \mathrm{~h}$ posttreatment and ovulation (OV) before $144 \mathrm{~h}$ posttreatment (27/35); panel B (cow \# 4099) describes a cow in which the d-13 CL did not regress and the dominant follicle did not ovulate (3/35); panel C (cow \# 4189) describes a cow in which the d-7 CL did not regress and the dominant follicle did not ovulate (2/35); panel D (cow \# 4195) describes a cow with delayed luteolysis after $56 \mathrm{~h}$ posttreatment and ovulation after $144 \mathrm{~h}$ posttreatment (2/35); and panel $\mathrm{E}$ (cow \# 4290) describes the cow that underwent luteolysis before $56 \mathrm{~h}$ posttreatment, but did not ovulate (1/35).

Serum concentrations of $\mathrm{E}_{2}$ were less $(P=0.048)$ at 84 and $96 \mathrm{~h}(P=0.05)$ in cloprostenol sodium compared with dinoprost tromethamine after treatment. No association was found for peak concentrations of $\mathrm{E}_{2}$ and time from treatment to ovulation $(P=0.83)$.

\section{Dynamics of Luteolysis with Treatments Combined}

Serum concentrations of $\mathrm{P}_{4}$ decreased $(P<0.0001)$ from $6.54 \pm 0.27$ to $3.77 \pm 0.22 \mathrm{ng} / \mathrm{mL}$ in the first hour after treatment. Subsequently, a significant increase $(P$ 


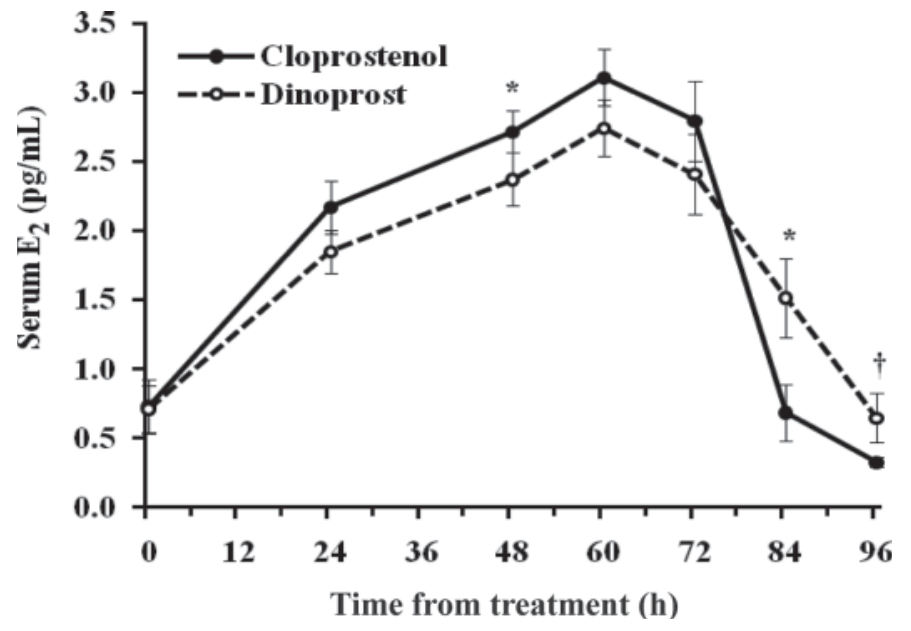

Figure 5. Mean $( \pm \mathrm{SEM})$ serum concentrations of estradiol $\left(\mathrm{E}_{2}\right.$; $\mathrm{pg} / \mathrm{mL}$ ) normalized to $\mathrm{PGF}_{2 \alpha}$ treatment in lactating dairy cows with at least one d-7 and one d-13 corpora lutea (CL) and treated with cloprostenol sodium or dinoprost tromethamine that had complete luteolysis by $56 \mathrm{~h}$ after $\mathrm{PGF}_{2 \alpha}$ and ovulated by $144 \mathrm{~h}$ after treatment $(27 / 35)$. Mean serum $\mathrm{E}_{2}$ concentrations were greater $(P=0.02)$ at 48 $\mathrm{h}$ after treatment for cloprostenol sodium compared with dinoprost tromethamine. Serum concentrations of $\mathrm{E}_{2}$ were less at $84 \mathrm{~h}(P=$ $0.048)$ and $96 \mathrm{~h}(P=0.05)$ after treatment in cloprostenol sodium compared with dinoprost tromethamine. $\dagger P=0.05$ and $* P<0.05$.

$<0.0001)$ in serum $\mathrm{P}_{4}$ occurred in the second hour after treatment from $3.77 \pm 0.22$ to $5.07 \pm 0.31 \mathrm{ng} / \mathrm{mL}$. Regression analyses indicated that serum concentrations of $\mathrm{E}_{2}$ at $24 \mathrm{~h}$ after $\mathrm{PGF}_{2 \mathrm{a}}$ injection were greater in cows when their serum concentrations of $\mathrm{P}_{4}$ at $12 \mathrm{~h}$ after $\mathrm{PGF}_{2 \alpha}$ were lower $(P=0.01$; Figure 6$)$.

Time from treatment to ovulation was positively related $(P<0.0001)$ to time from treatment to complete luteolysis (Figure 7). The regression equation for prediction of time from treatment to ovulation was $76.2 \mathrm{~h}$ $+(0.88 \times$ time from treatment to complete luteolysis $)$.

\section{DISCUSSION}

Results of the present study indicate that cloprostenol sodium had lower serum concentrations of $\mathrm{P}_{4}$ following induced luteolysis for the initial 12 -h period compared with dinoprost tromethamine. This difference might be due to the difference in resistance to endogenous metabolism between the products. Dinoprost tromethamine is metabolized in a similar mechanism to that of endogenous $\mathrm{PGF}_{2 \alpha}$ by 3 major steps. The initial metabolic step is the dehydrogenation of the $\mathrm{OH}$ group on $\mathrm{C}-15$ and reduction of the double bond at carbons 13-14 by the enzymes 15-hydroxydehydrogenase and 13,14-reductase. This rapid, initial metabolic step is followed by $\beta$-oxidation and $\omega$-oxidation (Oesterling et al., 1972; Bourne and Hathway, 1979; Bourne et al., 1980). Approximately $65 \%$ of dinoprost is metabolized in one

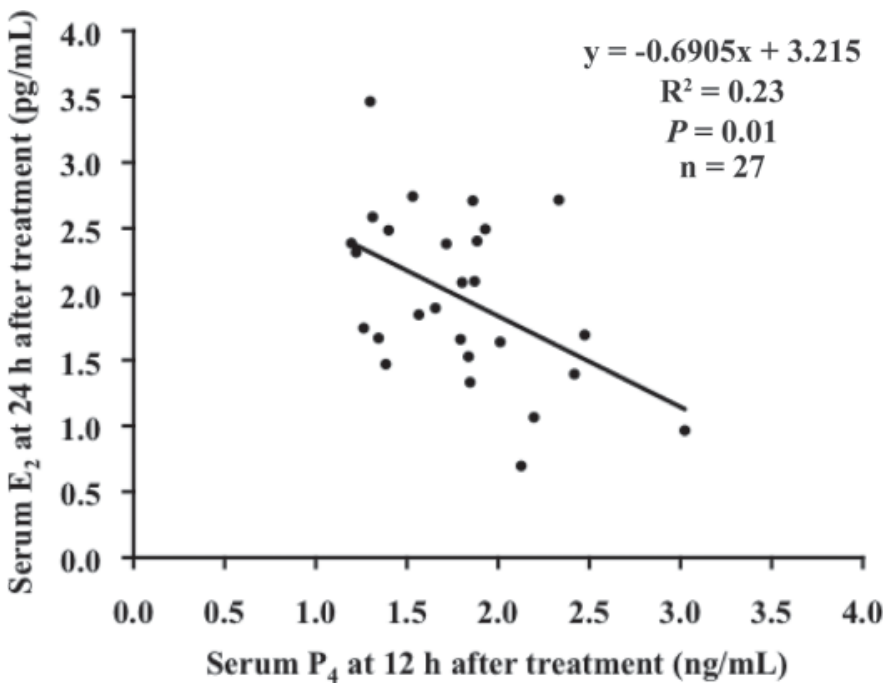

Figure 6. Regression analysis of the relationship between serum concentrations of progesterone $\left(\mathrm{P}_{4}\right) 12 \mathrm{~h}$ after treatment and serum concentrations of estradiol $\left(\mathrm{E}_{2}\right) 24 \mathrm{~h}$ after treatment in lactating dairy cows with treatments combined. Only cows with complete luteolysis and ovulation $(\mathrm{n}=27)$ were included.

passage through the lungs in the cow (McCracken et al., 1999). Cloprostenol has an oxyaryl moiety structure that blocks $\omega$-oxidation and the action of the dehydrogenase and reductase enzymes and reduces $\beta$-oxidation (Bourne et al., 1980). Therefore, cloprostenol is more resistant to endogenous metabolism and as a result has a much longer biological half-life $(\sim 3 \mathrm{~h}$; Reeves, 1978) than dinoprost tromethamine $(\sim 7-8 \mathrm{~min}$; Kindahl et al., 1976). Thus, the added time that cloprostenol is

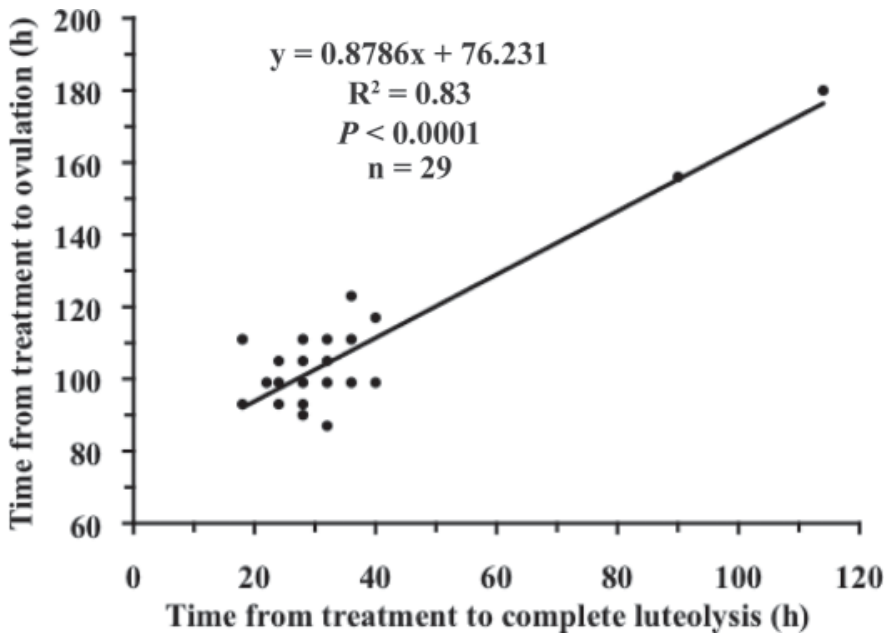

Figure 7. Regression analysis of the relationship between time from treatment to complete luteolysis and time from treatment to ovulation. All cows that had complete luteolysis (including delayed luteolysis) and ovulation (including ovulations after $144 \mathrm{~h}$ ) were included in this analysis $(\mathrm{n}=29)$. 
in circulation may have affected concentrations of $\mathrm{P}_{4}$ during the first $12 \mathrm{~h}$ posttreatment.

Subsequent concentrations of $\mathrm{E}_{2}$ were enhanced following treatment with cloprostenol sodium compared with dinoprost tromethamine. This difference may be due to increased pulses of LH due to a greater decrease in $\mathrm{P} 4$ in the cloprostenol group in the first $12 \mathrm{~h}$ following treatment. A study by Bergfeld et al. (1996) indicated that a more rapid decrease in $\mathrm{P}_{4}$ increased LH pulsatility, which in turn enhanced $\mathrm{E}_{2}$ production of the dominant follicle. When treatments were combined, a significant relationship was observed between the level of $\mathrm{P}_{4}$ in cows $12 \mathrm{~h}$ after treatment and subsequent concentrations of $\mathrm{E}_{2}$ in these cows $24 \mathrm{~h}$ posttreatment.

Luteolysis is one of several key steps in Ovsynch that is limiting to fertility in cows that are timedinseminated following Ovsynch. Previous data from our laboratory indicated that initiating Ovsynch on $\mathrm{d} 6$ of the estrous cycle increased $\mathrm{P}_{4}$ before $\mathrm{PGF}_{2 \alpha}$ of Ovsynch and more consistently controlled growth of the ovulatory follicle (Bello et al., 2006). In that study, both the level of $\mathrm{P}_{4}$ at the time of $\mathrm{PGF}_{2 \alpha}$ of Ovsynch and the size of the ovulatory follicle at time of final $\mathrm{GnRH}$ of Ovsynch were key factors in predicting the probability of pregnancy. These data indicated that the greater the ovulation rate to the first GnRH of Ovsynch, the greater the percentage of cows with accessory CL and increased $\mathrm{P}_{4}$. Three recently developed presynchronization strategies, Presynch-11(Galvão et al., 2007), G6G (Bello et al., 2006), and Double Ovsynch (Souza et al., 2008), increased the percentage of cows that had first-wave dominant follicles that could be responsive to the LH surge induced by the first injection of $\mathrm{GnRH}$ of Ovsynch compared with cows treated with Ovsynch at random stages of the estrous cycle. Thus, $7 \mathrm{~d}$ later at the time of the $\mathrm{PGF}_{2 \alpha}$ of Ovsynch, most cows that were presynchronized with these strategies would have a mature and an accessory CL that would have to undergo luteolysis to a single dose of $\mathrm{PGF}_{2 \alpha}$. In the current study, we chose to ensure that all cows had at least one d-13 and one d-7 CL at time of treatment to test potential differences between cloprostenol sodium and dinoprost tromethamine in the decrease of $\mathrm{P}_{4}$ in cows in this scenario. Our findings indicate that most cows had complete luteolysis, by our definition, following a single dose of cloprostenol sodium or dinoprost tromethamine. The only differences detected between these 2 luteolysins were decreases in $\mathrm{P}_{4}$ in the initial 12 $\mathrm{h}$ posttreatment and an increase in $\mathrm{E}_{2} 48 \mathrm{~h}$ posttreatment. Otherwise, no differences were uncovered in this study.

Because we used limited numbers of cows in this study to determine differences between treatments in percentages of cows that did not have complete lute- olysis, we report the efficacy of induced CL regression with cloprostenol sodium compared with dinoprost tromethamine in much greater numbers of cows in the companion paper (Martins et al., 2011).

A significant decrease in $\mathrm{P}_{4}$ levels was observed in the first hour after treatment followed by a rebound in the second hour for each cow. Ginther et al. (2007) reported a similar response in $\mathrm{P}_{4}$ concentrations in dairy heifers. This may be due to an acute increase in oxytocin. Studies indicated that $\mathrm{PGF}_{2 \alpha}$ injection acutely stimulated the release of oxytocin in vivo (Shaw and Britt, 2000; Keator et al., 2008) approximately 10-fold within 15 min. In the current study, all cows had a rebound in serum $\mathrm{P}_{4}$ concentrations in the second hour after treatment, and then all cows had a consistent decrease in $\mathrm{P}_{4}$, with the exception of the few cows that did not have complete CL regression. Time to complete functional luteolysis had a highly positive association with time to ovulation. Peak concentrations of $\mathrm{E}_{2}$ did not appear to influence time to ovulation, although all cows had an ovulatory follicle that was likely functional at time of treatment. The majority of cows had a $60-$ to $80-\mathrm{h}$ interval between time that $\mathrm{P}_{4}$ concentrations fell below $0.5 \mathrm{ng} / \mathrm{mL}$ and ovulation. Cows that did not have a decrease in $\mathrm{P}_{4}$ concentration to $<0.5 \mathrm{ng} / \mathrm{mL} 56 \mathrm{~h}$ posttreatment did not have ovulation of the dominant follicle. These follicles were most likely functional at time of $\mathrm{PGF}_{2 \alpha}$ due to the increase in $\mathrm{E}_{2}$ in each of these cows following treatment and the lack of a new follicular wave in the days that followed. In Ovsynch programs, the final GnRH-induced LH surge will likely ovulate this dominant follicle. Yet, if luteolysis does not occur in a timely manner, as seen in some cows of this study, conception rates may be affected negatively.

\section{CONCLUSIONS}

Cloprostenol sodium induced a greater decrease in serum $\mathrm{P}_{4}$ concentrations during the first $12 \mathrm{~h}$ following treatment compared with dinoprost tromethamine. No differences in the decrease in $\mathrm{P}_{4}$ were observed from $12 \mathrm{~h}$ until $144 \mathrm{~h}$ after treatment. The initial difference in the decrease in $\mathrm{P}_{4}$ during the first $12 \mathrm{~h}$ appeared to result in an increase in serum $\mathrm{E}_{2}$ concentration in cows treated with cloprostenol sodium.

\section{ACKNOWLEDGMENTS}

The authors acknowledge Schering Plough Animal Health Inc. (Union, NJ) for graduate assistant support, materials, and donation of Estrumate. We also thank Merial Limited (Iselin, NJ) for donation of Cystorelin. The authors express gratitude to the staff of the Michigan State University Dairy Teaching and Research 
Center (East Lansing), and to Fermin Jimenez-Krassel and Janet Ireland of the Department of Animal Science at Michigan State University for their assistance during the study.

\section{REFERENCES}

Bello, N. M., J. P. Steibel, and J. R. Pursley. 2006. Optimizing ovulation to first GnRH improved outcomes to each hormonal injection of Ovsynch in lactating dairy cows. J. Dairy Sci. 89:3413-3424.

Bergfeld, E. G., F. N. Kojima, A. S. Cupp, M. E. Wehrman, K. E. Peters, V. Mariscal, T. Sanchez, and J. E. Kinder. 1996. Changing dose of progesterone results in sudden changes in frequency of luteinizing hormone pulses and secretion of $17 \beta$-estradiol in bovine females. Biol. Reprod. 54:546-553.

Bourne, G. R., and D. E. Hathway. 1979. Prostaglandins and steroids. Pages 387-399 in Foreign Compound Metabolism in Mammals. Vol. 5. The Chemical Society, London, UK.

Bourne, G. R., S. R. Moss, P. J. Phillips, and B. Shuker. 1980. The metabolic fate of the synthetic prostaglandin cloprostenol ('Estrumate') in the cow: Use of ion cluster techniques to facilitate metabolite identification. Biomed. Mass Spectrom. 7:226-230.

Bridges, P. J., and J. E. Fortune. 2003. Characteristics of developing prolonged dominant follicles in cattle. Domest. Anim. Endocrinol. 25:199-214.

Brusveen, D. J., A. H. Souza, and M. C. Wiltbank. 2009. Effects of additional prostaglandin F2alpha and estradiol-17beta during Ovsynch in lactating dairy cows. J. Dairy Sci. 92:1412-1422.

Faul, F., E. Erdfelder, A. G. Lang, and A. Buchner. 2007. G*Power 3: A flexible statistical power analysis program for the social, behavioral, and biomedical sciences. Behav. Res. Methods 39:175-191.

Galvão, K. N., M. F. Sá Filho, and J. E. Santos. 2007. Reducing the interval from presynchronization to initiation of timed artificial insemination improves fertility in dairy cows. J. Dairy Sci. 90:4212-4218.

Ginther, O. J., L. A. Silva, R. R. Araujo, and M. A. Beg. 2007. Temporal associations among pulses of 13,14-dihydro-15-keto-PGF2alpha, luteal blood flow, and luteolysis in cattle. Biol. Reprod. $76: 506-513$.

Graham, J. D., and C. L. Clarke. 1997. Physiological action of progesterone in target tissues. Endocr. Rev. 18:502-519.

Kastelic, J. P., R. A. Pierson, and O. J. Ginther. 1990. Ultrasonic morphology of corpora lutea and central luteal cavities during the estrous cycle and early pregnancy in heifers. Theriogenology 34:487-498.

Keator, C. S., D. T. Schreiber, T. A. Hoagland, J. A. McCracken, and R. A. Milvae. 2008. Intrauterine infusion of BQ-610, an endothelin type A receptor antagonist, delays luteolysis in dairy heifers. Domest. Anim. Endocrinol. 34:411-418.
Kindahl, H., L. E. Edqvist, A. Bane, and E. Granstrem. 1976. Blood levels of progesterone and 15-keto-13,14-dihydro-prostaglandin F2alpha during the normal oestrous cycle and early pregnancy in heifers. Acta Endocrinol. (Copenh.) 82:134-149.

Martins, J. P. N., R. K. Policelli, L. M. Neuder, W. Raphael, and J. R. Pursley. 2011. Effects of cloprostenol sodium at final prostaglandin F2 $\alpha$ of Ovsynch on complete luteolysis and pregnancy per artificial insemination in lactating dairy cows. J. Dairy Sci. 94:2815-2824. 10.3168/jds.2010-3652

McCracken, J. A., E. E. Custer, and J. C. Lamsa. 1999. Luteolysis: A neuroendocrine-mediated event. Physiol. Rev. 79:263-323.

Moreira, F., C. A. Risco, M. F. Pires, J. D. Ambrose, M. Drost, and W. W. Thatcher. 2000. Use of bovine somatotropin in lactating dairy cows receiving timed artificial insemination. J. Dairy Sci. 83:1237-1247.

NRC. 2001. Nutrient Requirements of Dairy Cattle. 7th rev. ed. Natl. Acad. Sci., Washington, DC.

Oesterling, T. O., W. Morozowich, and T. J. Roseman. 1972. Prostaglandins. J. Pharm. Sci. 61:1861-1895.

Prendiville, D. J., W. J. Enright, M. A. Crowe, M. Finnerty, N. Hynes, and J. F. Roche. 1995. Immunization of heifers against gonadotropin-releasing hormone: Antibody titers, ovarian function, body growth, and carcass characteristics. J. Anim. Sci. 73:2382-2389.

Pursley, J. R., M. R. Kosorok, and M. C. Wiltbank. 1997a. Reproductive management of lactating dairy cows using synchronization of ovulation. J. Dairy Sci. 80:301-306.

Pursley, J. R., M. O. Mee, and M. C. Wiltbank. 1995. Synchronization of ovulation in dairy cows using PGF2alpha and GnRH. Theriogenology 44:915-923.

Pursley, J. R., M. C. Wiltbank, J. S. Stevenson, J. S. Ottobre, H. A. Garverick, and L. L. Anderson. 1997b. Pregnancy rates per artificial insemination for cows and heifers inseminated at a synchronized ovulation or synchronized estrus. J. Dairy Sci. 80:295-300.

Reeves, P. R. 1978. Distribution, elimination, and residue studies in the cow with the synthetic prostaglandin estrumate. J. Agric. Food Chem. 26:152-155.

Shaw, D. W., and J. H. Britt. 2000. In vivo oxytocin release from microdialyzed bovine corpora lutea during spontaneous and prostaglandin-induced regression. Biol. Reprod. 62:726-730.

Souza, A. H., H. Ayres, R. M. Ferreira, and M. C. Wiltbank. 2008. A new presynchronization system (Double-Ovsynch) increases fertility at first postpartum timed AI in lactating dairy cows. Theriogenology 70:208-215.

Souza, A. H., A. Gumen, E. P. Silva, A. P. Cunha, J. N. Guenther, C. M. Peto, D. Z. Caraviello, and M. C. Wiltbank. 2007. Supplementation with estradiol-17beta before the last gonadotropin-releasing hormone injection of the Ovsynch protocol in lactating dairy cows. J. Dairy Sci. 90:4623-4634. 